TITLE:

\title{
Managing risks and system performance in supply network: a conceptual framework
}

$\operatorname{AUTHOR}(S)$ :

Quang, Huy Truong; Hara, Yoshinori

\section{CITATION:}

Quang, Huy Truong ...[et al]. Managing risks and system performance in supply network: a conceptual framework. International Journal of Logistics Systems and Management 2019, 32(2): 245-271

\section{ISSUE DATE:}

2019-01-31

URL:

http://hdl.handle.net/2433/267776

\section{RIGHT:}

This is an accepted manuscript of this paper, which has been published in final form at

https://doi.org/10.1504/IJLSM.2019.097586.; The full-text file will be made open to the public on 31 January 2020 in accordance with publisher's 'Terms and Conditions for Self-Archiving'.; This is not the published version. Please cite only the published version. この論文は出版社版でありません。引用の際には出版社版をご確認ご利用ください。 


\title{
MANAGING RISKS AND SYSTEM PERFORMANCE IN SUPPLY NETWORK: A CONCEPTUAL FRAMEWORK
}

\begin{abstract}
Examining a certain risk will provide an insight into a single dimension, but a picture of different risks in the supply chain (SC) is still lacking, as risks do not take place independently, but typically simultaneously. This research aims to propose and validate a conceptual framework for linking various dimensions of risks to system performance in the SC. To this end, first, risks in supply network were identified by applying SC mapping - a new approach in SC risk body of literature. Then the theoretical conceptual framework comprising a holistic set of SC risks was proposed. In this model, risks were classified into three categories with regard to their level of impact on performance, i.e. core risks (supply, operational and demand risks), infrastructure risks (finance, information and time risks) and external risk. Empirical evidence at Vietnam construction industry showed that a total of nine SC risks were established. Accordingly, there are two new concepts formed from operational risk, namely (1) investor-related operational risks and (2) contractor-related operational risks. External risk moreover was split into two new dimensions: (1) human-made risks and (2) natural risks. Except for relationships between demand risk \& SC performance and between SC risks \& financial performance, these risks have mutual interaction and detrimentally affect SC performance. Using this framework, companies will have a systematic view of risks in the whole SC network whereby they can define risks in their own context and ascertain critical SC risks that cause negative effects on SC performance. Moreover, this framework can be used as a 'guidemap' in an effort to mitigate $\mathrm{SC}$ risks.
\end{abstract}

Keywords: Risk, Supply Chain Risk, Risk management, Supply chain risk management, Construction Sector.

\section{Introduction}

Risk can be described as a chance of danger, damage, loss, injury or any other undesired consequences (Harland et al., 2003). Even if a firm does everything well, risks are still prevalent (Cleland et al., 1981). Thus, we certainly cannot eliminate all risks, but it is possible to manage or minimize them (Rao Tummala and Leung, 1996).

The traditional view that provides the scope of risk management is concentrated on the company level (Jüttner, 2005). Supply chain (SC) risk management however considers the concept of risk in the whole supply chain network (Shenoi et al., 2016). A key issue in the literature is that empirical studies simultaneously examine diversified aspects of SC risks are limited (Ho et al., 2015). Previous work mainly concentrates on a specific risk such as supply (Ganguly and Guin, 2011) or finance (Cai et al., 2014).

Naturally, examining a certain risk will provide an insight into a single dimension, but a picture covering various risks in supply network is still lacking (Ho et al., 2015, Shenoi et al., 2016), as risks do not take place independently, but typically simultaneously. This is able to be a reason that leads to solutions of risk prevention not to achieve desired outcomes, since risk mitigation plans only focus on each single risk. More badly, in the worst case numerous risks simultaneously occur, if there are no appropriate contingency plans, it will engender extremely devastating consequences to firms/ their SC. Wagner and Bode (2008) indicated that a risk, when it occurs, can cause a domino effect, for 
instance, by empirical data at 760 German firms, the authors found that risks of information and finance can lead to the emergency of supply-, manufacturing- and demand risks.

Additionally, assessment of a specific risk can only explain a piece of the relationship between SC risk and performance. It is believed that if more risks that cover different aspects of SC are taken into account, greater understanding about the effect of SC risk on performance is yielded.

In the body of risk literature, there are so many approaches with regard to risk identification. Xie et al. (2011, p. 476) recommended applying SC mapping as a new approach to find out potential risks in the SC network.

[...] supply chain mapping is an approach in which the SC and its flow of goods, information and money is visually depicted, from upstream suppliers, throughout the focal firm, to downstream customers.

[...] once every detail of the supply chain has been mapped, potential risks can be identified better.

Therefore, through modelling SC, firms will have a visible and systematic view, whereby they can define risks in their context, so resources can be allocated appropriately and pertinent strategies implemented to mitigate risks. To this end, Ho et al. (2015) suggested that a comprehensive model needs to consider risks under a mutual interaction and should be validated by empirical data to consolidate validity and reliability of the model. Agreed to this, Wagner and Bode (2008, p. 308) argued that although risks are inherent in supply chains, with both their impact and management under greater scrutiny, current knowledge is still limited as results from large-scale empirical research are scarce and mostly descriptive.

Considering the above, this research aims to propose and validate a conceptual framework that covers various dimensions of risks in the SC network by empirical data gained from Vietnam construction sector. It can be expected that findings explored in this study are able to offer useful guidance for identifying and assessing SC risks, as well as facilitate further studies. From a practical perspective, the research results can highlight critical SC risks that cause negative effects on performance, and so some managerial implications are discussed to mitigate the effect of risks in the entire supply chain network.

The rest of this paper is as follows. Risks in supply network are modelled on SC map before a conceptual framework is proposed. The research processes and empirical results are then presented before a discussion section that considers the results of this study, which helps show topics for future research and concluding points.

\section{SC risks and the conceptual framework}

\subsection{Supply chain risk management process}

Risk management in supply chains is more of a recent phenomenon (Ho et al., 2015). Current studies explored risk management approaches from a variety of angles (Xie et al., 2011). Building on these studies, a structured risk management process includes the four critical phases: Risk identification, risk assessment, risk mitigation and risk monitoring were developed by Tummala et al. (1994). The risk management process was extensively applied in numerous individual project decisions, it however has not been employed yet to the much broader context of the supply chain (Xie et al., 2011, Kersten et al., 2011).

Xie et al. (2011) proposed that risk management in supply chain is a process of six critical steps grouped into three following phases.

- Phase 1: Risk Identification - Risk Measurement - Risk Assessment 
This phase begins with identifying risks and determining potential SC risks comprehensively and structurally. Subsequently, an evaluation of consequences and magnitudes of impact of all potential SC risks is conducted before a risk assessment is carried out to estimate the likelihood of each risk factor.

- Phase 2: Risk Evaluation - Risk Mitigation and Contingency Plans

In this phase, risk exposure values are calculated and acceptable levels of risk are established. Risk response action plans then are developed to contain and control risks.

- Phase 3: Risk Control and Monitoring

This final step aims to assess possible preventive measures and providing instructions for further improvement.

Of these three phases, the first one is a premise and has a significant effect on the whole process (Thun and Hoenig, 2011). Affected areas need to be clearly identified and consequences should be understood, whereby risk mitigation strategies can be executed (Xie et al., 2011). Many organizations and SCs start a risk management program without knowing what threats the organization faces, or what consequence a disruption would have. Consequently, they concentrate on protecting against the wrong threats and have ineffective plans against appropriate threats. Worse yet, they fail to anticipate important threats, or fail to recognize the consequence of a minor threat, magnifying its implications (Tang, 2006).

In the total of 169 reviewed journal articles published between 2003 and 2016, the number of risk identification studies are quite restrictive, especially empirical studies (Figure 1). Manuj and Mentzer (2008) indicated that there is a lack of conceptual frameworks and empirical findings to provide clear meaning and normative guidance on the phenomenon of global supply chain risk management. Ho et al. (2015) aims to a model of various risks and suggested more and more empirical research to confirm reliability of the model.

\section{INSERT FIGURE 1 HERE.}

As mentioned, a risk, when it incurs, can be a cause of another risk (Thun and Hoenig, 2011). In their framework, Ho et al. (2015) did emphasize importance of mutual interaction among risks. Chopra and Sodhi (2012) argued that efforts should be considered since some strategies might detrimentally affect other risks. Hence, understanding the variety and interrelationships of SC risks is extremely important.

\subsection{Supply chain mapping}

Xie et al. (2011, p. 476) summarized some approaches to identify potential SC risks, being:

[...] SC mapping is an approach in which the supply chain and its flow of goods, information and money will be schematically depicted, from upstream (suppliers), throughout the focal firm, to downstream (customers) (Gardner and Cooper, 2003).

[...] checklists or checksheets are forms to record how often a failure was attributed to a certain event (Chase et al., 2004).

[...] event tree or fault tree analyses are graphical representations of all possible and subsequent outcomes triggered by an event, e.g. a supply chain failure (Paté-Cornell, 1984). 
[...] failure mode and effect analysis (FMEA) is a tool to identify "at the design stages potential risks during the manufacture of a product and during its use by the end customer" (Karim et al., 2008).

[...] Ishikawa cause and effect analysis (CEA) involves the brainstorming and exploration of all possible relationships between potential causes and failure events (Chase et al., 2004).

Among these approaches, supply chain mapping was proposed as a new one to identify potential risks in SC network (Xie et al., 2011). A supply chain map aims to align supply chain strategy with corporate strategy, show/ clarify boundary setting, and help firms manage and modify the supply chain (Gardner and Cooper, 2003). Once every detail of the SC has been modelled, potential risks can be identified better (Xie et al., 2011). Gardner and Cooper (2003) proposed that geometry, perspective and implementation issues are three critical points in modelling a certain supply chain:

1. Geometry refers to defining the number of tiers that can be described by direction and length. The direction can be up the channel (Supplier-Oriented) from the focal firm, down the channel toward the final consumer (CustomerOriented), or both. Meanwhile, length is the distance out from the focal firm. For example, our model covers both up and down the channel of distribution, the length of $1 / 1$, meaning that 1 tier up and 1 tier down from the focal firm, i.e. Suppliers - Focal firm - Customers.

2. Perspective refers to focal point and scope that aim to describe the view depicted by the supply chain map. A supply chain map can analyse a perspective from a focal firm, or a perspective covering a competitive set of firms. Hence, firmcentric and industry-centric views are both possible as focal points. With regard to scope, there are different ways to define scope, in which adapts from definition of SC risk, as our point of view, is a comprehensive approach. Jüttner et al. (2003) stated that SC risk is any failures aligning to flows - from original suppliers to delivery of final products for the final user. This definition was shared by many academicians (Ho et al., 2015). Hence, scope of risk in supply chain will be identified on three main flows, i.e. product - information - finance flows.

3. Implementation issues indicate how the map will provide information and be disseminated, emphasizing the role of information in the chain.

As these instructions, our SC map is visually depicted in the Figure 2. Accordingly, this supply chain representation: 1) depicts both directions, one tier down and one up, 2) chooses a firm focal perspective, 3) covers three flows of the supply chain, 4) is low in information density. Moreover, this Figure is separated into five sections that risks can exist, e.g. (1) at suppliers; (2) processes from suppliers to focal firm and vice versa; (3) at focal firm; (4) from focal firm to customer and vice versa and (5) at customers. Table 1 summarizes potential risks in the literature with respect to these five sections.

\section{INSERT TABLE 1 HERE.}

The risks in the table 1 are then filtered throughout structural interviews of three academicians and five practitioners who have expertise in logistics and SC management. The selected risks are grouped in corresponding types of risk that are discussed below.

INSERT FIGURE 2 HERE. 


\subsection{Conceptual framework}

As schematically depicted in the figure 2, there are three critical flows in the SC map, including:

The product flow typically involves the movement of materials throughout various nodes along the SC from the raw material source to the final consumer. Starting with the upstream that supplies input for the main process of the focal firm, supplier bankruptcy and price fluctuations are major concerns (Xie et al., 2011, Chopra and Sodhi, 2012, Ketikidis et al., 2006, Shenoi et al., 2016). As finished products of suppliers are transported to focal firm, issues such as inadequate quality and quantity of inputs cause a domino effect through the SC to the final customer (Zsidisin et al., 2000). Lee and Billington (1993) indicated that capacity shortages and poor logistics performance are outcomes that derive from supplier-related risks. Moreover, these risks may have detrimental effects on the customer's costs and competitiveness (Zsidisin and Ellram, 2003). Wilderness AT is an example of supply risk, with tire issues in 2000. A quality issue was discovered that related to supply risk, resulting in 174 reported deaths and an estimated cost of \$2.1billion due to a recall (Truett, 2001). A further case is Robert Bosch, who was concerned as the company delivered its customers with defective highpressure pumps for diesel fuel injection systems in the beginning of 2005. A sub-supplier of Bosch was accountable for this fault, leading to millions of dollars in costs and affecting the entire supply chain.

In the focal firm, changes in design and technology are likely to occur (Tuncel and Alpan, 2010, Samvedi et al., 2013, Xie et al., 2011). These risks increase project costs (Williams et al., 1995) and disrupt operating activities, resulting in a decrease of expected return (Kim and Chavas, 2003). Mitsubishi Aircraft Corp. announced that delivery of the new Mitsubishi Regional Jet might be delayed for a fifth time due to technical problems, resulting in shares to decline $2.7 \%$ and extending their losses this year to $20 \%$. The jetliner, which seats 70 to 90 passengers, is designed for short- to medium-haul flights and consumes $20 \%$ less fuel than similarly sized aircraft. Experts believed that any subsequent design changes could force Mitsubishi Aircraft to review production plans, leading to a substantial delay in the plane's delivery, but manufacturing operations had already started.

Also at operations process of the focal firm, labour accidents and disputes are risks probably existing at any SC. The Health and Safety Executive statistics revealed that more than 27 million working days were lost between 2011 and 2012 due to occupational illness or personal injury (Kate, 2013). In the case study of Caterpillar - the world's largest manufacturer of construction machinery, Mas (2004) documented that during a dispute, the price was discounted by about 4 percent. Product quality declined and the consequential result was a $\$ 240$ million decrease in revenue. Ho et al. (2015) identified the risks occurring at the focal firm as operational risks.

As the physical flow moves to downstream, demand-related risks, such as demand variability, high competition in the market, customer bankruptcy and customer fragmentation, when incurred, make firms unable to forecast real market demands (Shenoi et al., 2016, Vishwakarma et al., 2016). Consequently, operating activities are disordered, costs overrun, resulting in revenues and profits falling (Fleischhacker and Fok, 2015). George et al. (2004) indicated that fluctuations in customer demands give rise to backlogging or shortages in the orders, planning flaws, bullwhip effect and have a deteriorating effect on the performance of stochastic inventory systems (Jemar" and Karaesmen, 2005). George also argued that rapid changes in customer expectations are a main cause of increasing product costs. Xu et al. (2010) concluded that demand uncertainty is an important factor for optimal decisions and expected profit. 
As discussed above, supply, operational and demand risks are ones pertaining to product flow, known as core risks. These risks are ordinary workday problems that might directly affect supply chains (Rice and Caniato, 2003). Each risk has different attributes that lead to various impacts on SC performance as illustrated. (Thun and Hoenig, 2011) indicated that core risks have a high likelihood to occur but lower impact on performance than external SC risks. Thus, we propose the following hypotheses:

\section{H1: Core risks are negatively related to SC performance.}

The second flow of the chain, finance, begins with the customers, back through the other nodes in the chain. This flow has an extremely important role that "feeds" activities in supply network. However, risks associated with finance flow diminish benefits of the chain. Factors of this risk, e.g. inflation, interest rates, currency fluctuations, stakeholder requests, etc., engender price fluctuations in supply activities, operation planning, labour disputes, demand variability and SC disruptions (Shenoi et al., 2016). For instance, inflation leads to continuously increased prices that irritate consumers who place the blame on producers. This is a reason for demand variability (Parks, 1978). Firms try to avoid raising prices and in doing so they prefer to lock material costs with long-term contracts, although this hurts their suppliers. Inflation also disrupts operations planning. Companies that wish to plan ahead encounter difficulty in the presence of uncertainty. They may have problems with budgeting since they are unsure about costs. Moreover, since the inflation rate is high, employees request higher wages from employers that engender labour disputes.

Regarding interest rates, Mitra et al. (2013) argued that as it increases, banks charge more for business loans, resulting in reducing the ability of customers to buy products and services, thus raising demand risk. This phenomenon can cause price fluctuations in supply activities (Lee et al., 2016).

Two other finance risks are currency fluctuations and stakeholder requests. While the first one has received much attention from academicians, having various effects on output growth and price, it is particularly true of multinational companies or foreign partners (Kandil and Mirzaie, 2005), till 2014 stakeholder requests were initially suggested as a finance risk by Ackermann et al. Accordingly, stakeholders have influences on particular dimensions and typically have a strong voice in company direction. They participate in the daily operations of the business or vote on critical decisions that affect activities of operation plans. Moreover, these members are able to monitor supplier selection, company's outsourcing activities and globalization initiatives, and may vote against business decisions.

The last flow - information, aligns the relationship between the SC's various stages, allowing them to coordinate their actions and maximize total SC profitability. However, lack of information or incorrect information passed through the SC leads to excessive inventory investment, misguided capacity plans, missed production schedules, ineffective transportation, poor customer service and lost revenues (Lee et al., 2004). Moreover, distorted information throughout the SC can amplify the bullwhip effect (Handfield and Nichols, 2002). A customer information leak at Benesse, a Japanese company which focuses on correspondence education and publishing, by a systems engineer led to second quarter (2015) consolidated revenue down 7\% from the same period of the previous fiscal year, with operating profit also decreasing $88 \%$ and 280,000 customers being lost (Ishii and Komukai, 2016).

In the SC, Ho et al. (2015) argued that there are several "infrastructure" elements which aim to ensure the healthy functioning of the chain, such as finance or information. As discussed above, any disruptions relating to these elements can lead to serious problems for processes in the supply chain - especially supply, manufacturing and downstream activities (Wagner and Bode, 2008). Another important infrastructure element is time. Delays in activities cause serious issues that can disrupt firms operations 
(Shenoi et al., 2016). A firm can expect additional costs as they have to pay for an idle workforce and underutilized equipment during the course of the delay. Sambasivan and Soon (2007) confirmed that time-related risks in projects give rise to the dissatisfaction of all the parties involved. For instance, information delays can breakdown communication among members in project teams and in the SC (Angulo et al., 2004). These delays in the delivery of products to customers can cause bankruptcy of partners (Bernanke, 1981), or delays in payment - and are some of the main reasons for disputes (Aibinu and Jagboro, 2002). It is worth mentioning that although time source-related risks exist in the SC risk management literature, there is a shortage of accessing these risks as an independent entity. All above, we propose the following hypothesis:

H2: Infrastructure risks are negatively related to core risks.

Wagner and Bode (2008), based on the contingency theory and the strategic management, suggested to extend the scope of risk, stating that high organizational efficiency and performance results when firms consider the context in which strategy is crafted and implemented. As such, firms must match structure to the context and environment, i.e., forces outside the decision-maker's control. If this "fit" is not reached, "opportunities are lost, costs rise, and the maintenance of the organization is threatened" (Child, 1972). Agreeing with this discussion, Thun and Hoenig (2011), in a rare empirical study, proved that there is a significant difference between internal and external SC risks in terms of impact on performance.

External risks deal with threats from an external perspective of SC that can be caused by economical, socio-political or geographical reasons. Examples are fire accidents, natural catastrophes, economic downturn, external legal issues, corruption, cultural differentiation (Samvedi et al., 2013, Wu et al., 2006, Shenoi et al., 2016, Vishwakarma et al., 2016). These risks rarely occur but can lead indirectly to disturbances within the supply chain. For instance, a fire at a Phillips semiconductor plant in 2000 led to disruptions in operational processes, which eventually engendered a $\$ 400$ million loss for Ericsson (Chopra and Sodhi, 2012). Another example is the earthquake, tsunami and the subsequent nuclear crisis in Japan (2011) which caused Toyota's production to drop by 40,000 vehicles, resulting in a loss of $\$ 72$ million in profit per day (Pettit et al., 2013). Toyota also decided to stop production in its US-based plants after the terrorist attacks of September 11, which caused significant delays in delivery of parts coming from foreign countries (Sheffi, 2001). Thus, we propose the following hypotheses:

H3: External risks are negatively related to core risks and infrastructure risks.

\section{INSERT FIGURE 3 HERE.}

Figure 3 visually depicts our theoretical framework, in which, as discussed SC risks are separated into three levels, being:

- The first level is core risks that directly affect SC performance. These risk types align with physical flow, including supply-, operational- and demand risks.

- The second level is infrastructure risks, e.g. information and finance risks that cause negative effects on physical activities in the SC, increasing core risk seriousness. Time risk is also known as infrastructure risks, but the scope and the consequence are larger. Thus, time risk influences physical, finance and information flows from an internal perspective of the SC.

- The third level is external risks, e.g. natural catastrophes, economic downturns, etc., having a comprehensive effect on all activities in the SC network. 
The centre of this conceptual framework is performance, which is used to examine the degree of risk in the SC. Traditionally cost is recognized as a key performance indicator (KPI) for assessing the efficiency of the supply chain. It is one of the main objectives in supply chain management as minimizing cost and waste, results in a higher performing supply chain. However, this measure tends to be historical and does not demonstrate the current situation of the business environment as well as prospects for future performance (Quang et al., 2016).

The balanced scorecard model, developed by Kaplan and Norton (1992) recognizes the limitations of traditional performance measurements and translates a firm's strategies into performance objectives. The scorecard has four balanced perspectives, including financial, customer, internal processes and innovation \& learning. It focuses on intangible assets such as innovation, value chain, employee skills and knowledge and customer and supplier relationships etc. This new approach shifts the conventional focus on physical assets to emphasising both physical and intangible resources in a chain, which help a firm develop in the long-term.

This study defines a set of measures for SC performance based on the four aspects of the balance scorecard model (Table 2). Accordingly, five crucial dimensions are proposed, including: supplier performance, internal business, innovation and learning, customer service and finance.

\section{INSERT TABLE 2 HERE.}

\section{Research process}

\subsection{Development of questionnaire}

Based on an extensive literature review of SC risk management and records from the structure interviews with academicians and practitioners, at first, a preliminary questionnaire was developed. The Likert scale was used to extract the different opinions of respondents, and the extent they agree/disagree with statements that aim to assess degree of danger for each risk and evaluate each indicator of SC performance. A fivepoint scale was employed with a score of 1 indicating, "strongly disagree" and a score of 5 representing "strongly agree". This questionnaire was provided to 11 construction firms to verify effectiveness before conducting a large-scale survey.

\subsection{Large-scale data collection}

Data used in this research belong to a large-scale survey supported by a project of the Japanese government that aims to promote sustainable socio-economic development of the ASEAN region. The target population is Vietnam-based companies within the construction industry. This sector is key in economies throughout the world. However, compared to many other industries, it is inherently risky due to its unique characteristics such as the manufacturing facilities or plants must be located at the construction site, long timeframes, complicated processes, unpredictable environments, financial intensity, complex relationships and dynamic organisation structures. As a result, work related accidents are typical and a reputation for being unable to resolve issues develops. Furthermore many projects fail to meet deadlines, cost and quality targets. Typically, a $10 \%$ contingency is added to the total project cost to accommodate for unforeseen 
circumstances. Hence, the construction sector is selected to validate our conceptual framework.

The target respondents were managers, coordinators, etc., who have knowledge and experience of logistics and SC management. As a result, there are 202 companies participating in the survey. The table 3 provides information regarding the survey sample.

\section{INSERT TABLE 3 HERE.}

\subsection{Large-scale data analysis process}

The process of data analysis starts with Exploratory Factor Analysis (EFA), which is conducted to uncover the underlying structure of observed variables. Following this, Cronbach's Alpha coefficients are calculated to assess the reliability of measurement scales. Subsequently, Confirmatory Factor Analysis (CFA) tests the developed constructs to confirm convergent validity, unidimensionality, discriminant validity and criterionrelated validity. These three steps are conducted repeatedly until the constructs are unidimensional, reliable and valid.

\section{Results}

The EFA and Cronbach's Alpha testing results are presented in Table 4. The table indicates that after removing some measuring items that are not within the threshold values, all of the research concepts are valid and reliable. Operational and external risks were also separated into specific constructs. Two new concepts establishing from operational risk, being:

(1) OP1 that includes the risk factors of design changes and technological changes;

(2) OP2 comprising accidents and labour disputes.

External risk was also split into two new constructs:

(1) ER1 that encompasses economic downturns, external legal issues and corruption;

(2) ER2 consisting of fire accidents and natural catastrophes.

\section{INSERT TABLE 4 HERE.}

The test results of CFA (Table 5) show that all Standardized Regression Coefficients of the remaining items are greater than twice standard error, $\mathrm{R}^{2}>0.3$. This confirms that the measuring items have convergent validity.

\section{INSERT TABLE 5 HERE.}

Regarding unidimensionality, seven measurement models of research concepts are evaluated. Table 6 presents the goodness of fit of measurement models. The results show all models fit with the data proving all seven concepts are unidimensional. 


\section{INSERT TABLE 6 HERE.}

Table 7 describes the Chi-square difference among research concepts, which is used to test discriminant validity. 21 pairs coupled from the seven research concepts are compared through two models for each pair. The first model is to allow free correlation between the two constructs, and the other is to fix the correlation between the two constructs at 1.0. The research results indicated that all differences among research concepts are significant at $\mathrm{P}<0.001$. Thus, we can conclude that all research concepts are discriminant.

\section{INSERT TABLE 7 HERE.}

Criterion-related validity is tested through Pearson's correlation coefficient (Table 8). There are three critical parts in this test. The first one is the impact of the core risks on SC performance. We can see that while demand risk does not have effect on any indicators of $\mathrm{SC}$ performance, operational risk and supply risk have relatively high correlation to dependent variables except financial indicators. The second and third are relationships among external risks, infrastructure risks and core risks that mostly support for our theoretical framework. Hence, research concepts have criterion-related validity.

\section{INSERT TABLE 8 HERE.}

From the above, we can conclude that after removing several items which do not meet threshold values, a set of various SC risks that are valid, reliable and unidimensional are produced.

\section{Discussion}

This research has identified various risks in the SC network. After a careful testing process of a dataset from Vietnam's construction sector, and comparing with seven original risks, a total of nine SC risks were established. First, there are two new concepts formed from operational risk, namely OR1 and OR2. These two risks, though all relate to operational process of the focal firm, are very different in terms of who will be responsible. For instance, OR1 comprises design and technological changes, which normally originate from investor decisions. Thus, they will incur any time and cost overruns. In contrast, OR2 is risks that derive from contractors, e.g. accidents that occur if the working conditions are poor or labour disputes due to unfair remuneration and workplace conflict. Hence, with these risks, the contractors are responsible. OR1 and OR2, therefore, are renamed as (1) investor-related operational risks and (2) contractorrelated operational risks. Second, external risk is split into two new dimensions: (1) human-made risks (ER1), including economic downturns, external legal issues and corruption and (2) natural risks (ER2), comprising fire accidents and natural catastrophes. 
The Pearson's correlation results also confirmed the distinction between OR1 and OR2. Although both OR1 and OR2 belong to the operational risk, their behaviours are very different. While OR1 has positive correlations to Innovation \& Learning $\left(.143^{*}\right)$ and Customer Service (.156*), there is no statistical significance in OR2. Moreover, the impacts of some infrastructure risks on operational risk are only found in OR1, e.g. financial risk $(.151 *)$ and information risk $(.267 * *)$. Conversely, time risk and external risk having effect on OR2 are $\mathbf{. 1 7 8 *}$ and $.397 *$ respectively. Likewise with external risk, the correlation with other risks is also different between two new concepts. For instance, whilst human-made risks uniquely affect operational risk $(.288 * *)$, only natural risks influence on supply risk $(.233 * *)$ and time risk $(.391 * *)$. These findings support the splitting of the operational and external risks into the specific dimensions.

\section{INSERT FIGURE 4 HERE.}

Figure 4 schematically depicts the relationship between risks and SC performance. Core risks, including supply risk and operational risk, have direct effect on SC performance indicators. Particularly, supply risk causes failures to deliver inbound goods or services to the purchasing firm. As a result, it not only directly affects performance of suppliers themselves, but disrupts internal business of the purchasing firm and subsequently throughout the downstream SC, i.e. reducing quality of customer service. Regarding operational risk, when it incur, also disrupting internal business of the focal firm and decrease quality of customer service. Moreover, this type of risk affects innovation and learning activities of the focal firm that decrease number of new product developed and workforce flexibility.

The research also found the relation of the infrastructure risks to the core risks, being:

- Lack of information or distorted information passed from one end of the SC to the other, causing significant problems for suppliers, e.g., misguided capacity plans, ineffective transportation, and missed production schedules, excessive inventory investment, etc., that increase supply risk.

- Finance risk disrupts operations planning. Companies that wish to plan ahead may find it difficult in the presence of financial uncertainty. They may have problems with budgeting since they are unsure about their costs. Moreover, financial risk, e.g. inflation, can lead to a phenomenon that employees require higher wages from employers. This phenomenon can engender labour disputes that are one of operational risk's factors.

- Failure to achieve targeted time can lead to risks of information, supply and demand. Particularly, information delays can breakdown communication among members in project teams and in the SC (Angulo et al., 2004). More seriously, delays in the delivery of products to customers can cause bankruptcy of partners (Bernanke, 1981). Sambasivan and Soon (2007) also confirmed that delays in construction projects give rise to dissatisfaction to all the parties involved.

From external perspective, external risks cause serious troubles for all activities in the chain. For instance, economic downturn, when it occurs, leads to the changes in financial policies, makes operating business environment highly dynamic and difficult (Hansen et al., 2013), or even breaks relationship between suppliers - buyers (Krause and Ellram, 2014). Likewise, natural disasters raised trading and security costs, cause delays in activities (Oh, 2015), and in some bad conditions, they can breakdown information infrastructure (Petrucci, 2012). Moreover, the existence of a larger number of procedures 
engenders delays, difficulties in transactions among members in the SC network (Dreher and Gassebner, 2013), and access to capital (Adair, 2006), etc.

Meanwhile, there are no relationships that are found between demand risk \& any indicators of SC performance as well as SC risks \& financial performance. Perhaps, demand risk affects $\mathrm{SC}$ performance throughout other risks/ factors, i.e. indirect effect. Likewise, the impact of SC risks on financial indicators will be found if we consider the relation of other SC performance indicators to financial performance, i.e. mediation relationship. Future research should take this statement into consideration to extend the picture of risks and performance in the supply network.

In summary, the proposed conceptual framework aims to have a systematic view of risks in the whole SC network. Using the framework, companies can define risks in their own context and ascertain critical SC risks that cause negative effects on SC performance. Moreover, in an effort to mitigate risks in the SC network, this framework can be used as a 'guide-map'. Mitigation plans should start with the core risks. Particularly, supply risk and operational risk are ones that directly affect SC performance. Demand risk, though not correlating with $\mathrm{SC}$ performance can have indirect effect through operational risk and supply risk. Thus, since operational risk and supply risk are controlled, the impact of demand risk on SC performance will be remarkably decreased.

Additionally, mitigation plans for the core risks also pay attention on the influence of the infrastructure risks on the core risks, e.g. information risk on supply risk and financial risk on operational risk. Restricting this impact, one side is able to reduce degree of danger of the core risks, moreover, the impact of the infrastructure risks on SC performance will be significantly decreased on the other side. Then the reasons for delays need to be investigated and mitigated against. Finally external risk needs to be considered. Whilst rare, their impacts can be potentially devastating on all activities in the SC network. To this end, it is imperative to have supports from Associations, Governments, etc.

\section{Conclusions and future research}

There are three main phases in the SC risk management process (Xie et al., 2011). This research focuses on the first one that numerous risks in the SC network were identified and assessed. By the SC mapping approach, a technique that was recommended for a long time but were not used popularly in the SC risk body (Gardner and Cooper, 2003), nine critical risks (four core-, three infrastructure- and two external risks) were established. These risks have interrelationship and various impact on SC performance. The empirical evidence gained from the Vietnam construction industry proved the validity and reliability of the conceptual framework. This can be a premise for the next phase, especially risk monitoring which received less attention in academic studies.

According to Sampaio et al. (2016), SC risk is an extensive concept. Therefore, despite this research attempting to integrate various dimensions of $\mathrm{SC}$ risks in a conceptual framework, it is imperative to validate this framework in a range of contexts in different sectors and supply chains. Each sector/SC will have disparate characteristics that been to be considered. Therefore, like risk sources and types, the risk factors will be distinct among different industries/SCs, such as the public sector, renewable energy sector and bioenergy, biomass and service, which were all missing in the literature. These distinct risk factors should be integrated into the framework under the corresponding SC risk types. This reflects the characteristics of industries/SCs but it is still necessary to define a more comprehensive model.

Another approach can be examining and analysing risks in the SC under industrycentric focus. This approach aims to a broader view and can be a platform to suggest 
implications/solutions for Associations, Governments in the effort of risk mitigation and monitoring.

In the scope of this research, there are some relationships that are not supported. Perhaps, they will be significant if more interrelations that indicate indirect effects are examined. Otherwise, among four new established concepts, investor- \& contractorrelated operational risks and natural risk contain only two measurement items that somewhat detract reliability of constructs. Future research should base on characteristics of survey industries/ research contexts, adding new SC risk factors that aim to increase reliability of these research concepts. Furthermore, to fully examine SC risks, the next empirical studies should also take into account past risk behaviours and the likelihood of occurrence instead of only looking into the level of impact mentioned in this research. The above discussion implies new directions for researchers.

\section{References}

Ackermann, F., Howick, S., Quigley, J., Walls, L. \& Houghton, T. (2014), "Systemic risk elicitation: Using causal maps to engage stakeholders and build a comprehensive view of risks", European Journal of Operational Research, Vol. 238, No. 1, pp. 290-299.

Adair, T. (2006), "Pensions, Risks, and Capital Markets", The Journal of Risk and Insurance, Vol. 73, No. 4, pp. 559-574.

Aibinu, A. \& Jagboro, G. (2002), "The effects of construction delays on project delivery in Nigerian construction industry", International journal of project management, Vol. 20, No. 8, pp. 593-599.

Angulo, A., Nachtmann, H. \& Waller, M. A. (2004), "Supply chain information sharing in a vendor managed inventory partnership", Journal of business logistics, Vol. 25, No. 1, pp. 101-120.

Bernanke, B. S. (1981), "Bankruptcy, liquidity, and recession", The American Economic Review, Vol. 71, No. 2, pp. 155-159.

Cai, G. G., Chen, X. \& Xiao, Z. (2014), "The roles of bank and trade credits: Theoretical analysis and empirical evidence", Production and Operations Management, Vol. 23, No. 4, pp. 583-598.

Chase, R. B., Aquilano, N. J. \& Jacobs, F. R. (2004), Operations management for competitive advantage, McGraw-Hill Companies.

Child, J. (1972), "Organizational structure, environment and performance: The role of strategic choice", sociology, Vol. 6, No. 1, pp. 1-22.

Chopra, S. \& Sodhi, M. (2012), "Managing risk to avoid supply-chain breakdown", MIT Sloan Management Review (Fall 2004), Vol. 46, No. 1, pp. 53-61.

Cleland, D. I., Kocaoglu, D. F., Brown, J. \& Maisel, J. (1981), Engineering management, McGraw-Hill, New York, NY.

Dreher, A. \& Gassebner, M. (2013), "Greasing the wheels? The impact of regulations and corruption on firm entry", Public Choice, Vol. 155, No. 3, pp. 413-432.

Fleischhacker, A. J. \& Fok, P.-W. (2015), "On the relationship between entropy, demand uncertainty, and expected loss", European Journal of Operational Research, Vol. 245, No. 2, pp. 623-628.

Ganguly, K. K. \& Guin, K. K. (2011), "Understanding supply risk in supply chain: a fuzzy framework", International Journal of Logistics Systems and Management, Vol. 8, No. 3, pp. 267-283. 
Gardner, J. T. \& Cooper, M. C. (2003), "Strategic supply chain mapping approaches", Journal of Business Logistics, Vol. 24, No. 2, pp. 37-64.

George, A. Z., Lisa, M. E., Joseph, R. C. \& Joseph, L. C. (2004), "An analysis of supply risk assessment techniquesnull", International Journal of Physical Distribution \& Logistics Management, Vol. 34, No. 5, pp. 397-413.

Handfield, R. B. \& Nichols, E. L. (2002), Supply chain redesign: Transforming supply chains into integrated value systems, FT Press, New Jersey.

Hansen, E., Nybakk, E. \& Panwar, R. (2013), "Firm performance, business environment, and outlook for social and environmental responsibility during the economic downturn: findings and implications from the forest sector", Canadian Journal of Forest Research, Vol. 43, No. 12, pp. 1137-1144.

Harland, C., Brenchley, R. \& Walker, H. (2003), "Risk in supply networks", Journal of Purchasing and Supply management, Vol. 9, No. 2, pp. 51-62.

Ho, W., Zheng, T., Yildiz, H. \& Talluri, S. (2015), "Supply chain risk management: a literature review", International Journal of Production Research, Vol. 53, No. 16, pp. 5031-5069.

Ishii, K. \& Komukai, T. A Comparative Legal Study on Data Breaches in Japan, the US, and the UK. IFIP International Conference on Human Choice and Computers, 2016. Springer, 86-105.

Jema1", Z. \& Karaesmen, F. (2005), "The influence of demand variability on the performance of a make-to-stock queue", European Journal of Operational Research, Vol. 164, No. 1, pp. 195-205.

Jüttner, U. (2005), "Supply chain risk management: Understanding the business requirements from a practitioner perspective", The International Journal of Logistics Management, Vol. 16, No. 1, pp. 120-141.

Jüttner, U., Peck, H. \& Christopher, M. (2003), "Supply chain risk management: outlining an agenda for future research", International Journal of Logistics: Research and Applications, Vol. 6, No. 4, pp. 197-210.

Kandil, M. \& Mirzaie, I. (2005), "The effects of exchange rate fluctuations on output and prices: evidence from developing countries", The Journal of Developing Areas, Vol. 38, No. 2, pp. 189-219.

Kaplan, R. S. \& Norton, D. (1992), "The Balanced Scorecard: Measures that Drive Performance", Harvard Business Review, Vol. 70, No. 1, pp. 71-79.

Karim, M., Smith, A. \& Halgamuge, S. (2008), "Empirical relationships between some manufacturing practices and performance", International Journal of Production Research, Vol. 46, No. 13, pp. 3583-3613.

Kate, S. (2013), "Health and Safety Executive - Annual Statistics Report for Great Britain 2012/13", available at: http://www.hse.gov.uk/statistics/overall/hssh1213.pdf (accessed 07 June 2016).

Kersten, W., Hohrath, P., Boeger, M. \& Singer, C. (2011), "A supply chain risk management process", International Journal of Logistics Systems and Management, Vol. 8, No. 2, pp. 152-166.

Ketikidis, P. H., Lenny Koh, S., Gunasekaran, A., Cucchiella, F. \& Gastaldi, M. (2006), "Risk management in supply chain: a real option approach", Journal of Manufacturing Technology Management, Vol. 17, No. 6, pp. 700-720.

Kim, K. \& Chavas, J. P. (2003), "Technological change and risk management: an application to the economics of corn production", Agricultural economics, Vol. 29, No. 2, pp. 125-142. 
Krause, D. \& Ellram, L. M. (2014), "The effects of the economic downturn on interdependent buyer-supplier relationships", Journal of Business Logistics, Vol. 35, No. 3, pp. 191-212.

Lee, H. L. \& Billington, C. (1993), "Material management in decentralized supply chains", Operations research, Vol. 41, No. 5, pp. 835-847.

Lee, H. L., Padmanabhan, V. \& Whang, S. (2004), "Information distortion in a supply chain: The bullwhip effect", Management science, Vol. 43, No. 4, pp. 546 - 558.

Lee, Y., Rösch, D. \& Scheule, H. (2016), "Accuracy of mortgage portfolio risk forecasts during financial crises", European Journal of Operational Research, Vol. 249, No. 2 , pp. $440-456$

Manuj, I. \& Mentzer, J. T. (2008), "Global supply chain risk management strategies", International Journal of Physical Distribution \& Logistics Management, Vol. 38, No. 3, pp. 192-223.

Mas, A. (2004). Three Essays on the Relationship Between Labor Disputes And Employee Performance: Dissertation Summary.

Mitra, S., Date, P., Mamon, R. \& Wang, I.-C. (2013), "Pricing and risk management of interest rate swaps", European Journal of Operational Research, Vol. 228, No. 1, pp. 102-111.

Oh, C. H. (2015), "How do natural and man-made disasters affect international trade? A country-level and industry-level analysis", Journal of Risk Research, Vol. 18, No. 1, pp. 1-23.

Parks, R. W. (1978), "Inflation and relative price variability", The Journal of Political Economy, Vol. 86, No. 1, pp. 79-95.

Paté-Cornell, M. E. (1984), "Fault trees vs. event trees in reliability analysis", Risk Analysis, Vol. 4, No. 3, pp. 177-186.

Petrucci, O. (2012), The Impact of Natural Disasters: Simplified Procedures and Open Problems, INTECH Open Access Publisher.

Pettit, T. J., Croxton, K. L. \& Fiksel, J. (2013), "Ensuring supply chain resilience: development and implementation of an assessment tool", Journal of Business Logistics, Vol. 34, No. 1, pp. 46-76.

Quang, H. T., Sampaio, P., Carvalho, M. S., Fernandes, A. C., An, D. T. B. \& Vilhenac, E. (2016), "An extensive structural model of supply chain quality management and firm performance", International Journal of Quality \& Reliability Management, Vol. 33, No. 4, pp. 444-464.

Rao Tummala, V. \& Leung, Y. (1996), "A risk management model to assess safety and reliability risks", International Journal of Quality \& Reliability Management, Vol. 13 , No. 8, pp. 53-62.

Rice, J. B. \& Caniato, F. (2003), "Building a secure and resilient supply network", Supply Chain Management Review, Vol. 7, No. 5, pp. 22-30.

Sambasivan, M. \& Soon, Y. W. (2007), "Causes and effects of delays in Malaysian construction industry", International Journal of Project Management, Vol. 25, No. 5, pp. 517-526.

Sampaio, M. S. C., Ana Cristina Fernandes, P., Cagnin, F., Oliveira, M. C., Simon, A. T., Helleno, A. L. \& Vendramini, M. P. (2016), "Proposal of a method for selecting suppliers considering risk management: An application at the automotive industry", International Journal of Quality \& Reliability Management, Vol. 33, No. 4, pp. 488-498.

Samvedi, A., Jain, V. \& Chan, F. T. (2013), "Quantifying risks in a supply chain through integration of fuzzy AHP and fuzzy TOPSIS", International Journal of Production Research, Vol. 51, No. 8, pp. 2433-2442. 
Sheffi, Y. (2001), "Supply chain management under the threat of international terrorism", The International Journal of logistics management, Vol. 12, No. 2, pp. 1-11.

Shenoi, V. V., Dath, T. S. \& Rajendran, C. (2016), "Supply chain risk management in the Indian manufacturing context: a conceptual framework", International Journal of Logistics Systems and Management, Vol. 25, No. 3, pp. 313-335.

Tang, C. S. (2006), "Perspectives in supply chain risk management", International Journal of Production Economics, Vol. 103, No. 2, pp. 451-488.

Thun, J.-H. \& Hoenig, D. (2011), "An empirical analysis of supply chain risk management in the German automotive industry", International Journal of Production Economics, Vol. 131, No. 1, pp. 242-249.

Truett, R. (2001), Tire-related costs mount for Ford. Automotive News.

Tummala, V. R., Nkasu, M. \& Chuah, K. (1994), "A framework for project risk management", ME Research Bulletin, Vol. 2, No. pp. 145-171.

Tuncel, G. \& Alpan, G. (2010), "Risk assessment and management for supply chain networks: A case study", Computers in Industry, Vol. 61, No. 3, pp. 250-259.

Vishwakarma, V., Prakash, C. \& Barua, M. K. (2016), "A fuzzy-based multi criteria decision making approach for supply chain risk assessment in Indian pharmaceutical industry", International Journal of Logistics Systems and Management, Vol. 25, No. 2, pp. 245-265.

Wagner, S. M. \& Bode, C. (2008), "An empirical examination of supply chain performance along several dimensions of risk", Journal of business logistics, Vol. 29, No. 1, pp. 307-325.

Williams, T., Eden, C., Ackermann, F. \& Tait, A. (1995), "The effects of design changes and delays on project costs", Journal of the Operational Research Society, Vol. 46, No. 7, pp. 809-818.

Wu, T., Blackhurst, J. \& Chidambaram, V. (2006), "A model for inbound supply risk analysis", Computers in industry, Vol. 57, No. 4, pp. 350-365.

Xie, C., Anumba, C. J., Lee, T.-R., Tummala, R. \& Schoenherr, T. (2011), "Assessing and managing risks using the supply chain risk management process (SCRMP)", Supply Chain Management: An International Journal, Vol. 16, No. 6, pp. 474-483.

Xu, M., Chen, Y. F. \& Xu, X. (2010), "The effect of demand uncertainty in a pricesetting newsvendor model", European Journal of Operational Research, Vol. 207, No. 2, pp. 946-957.

Zsidisin, G. A. \& Ellram, L. M. (2003), "An Agency Theory Investigation of Supply Risk M anagement", Journal of Supply Chain Management, Vol. 39, No. 2, pp. 15-27.

Zsidisin, G. A., Panelli, A. \& Upton, R. (2000), "Purchasing organization involvement in risk assessments, contingency plans, and risk management: an exploratory study", Supply Chain Management: An International Journal, Vol. 5, No. 4, pp. 187-198. 


\section{SECTIONS}

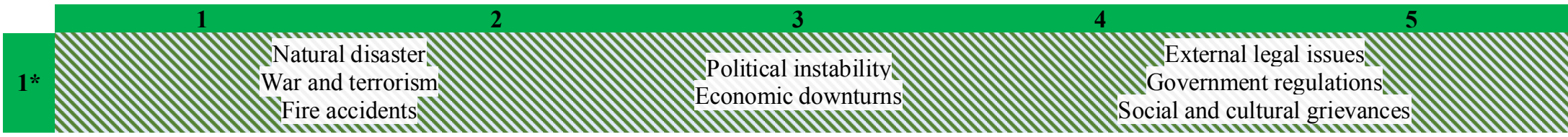

Selection of wrong partner Failures to make delivery

Supplier bankruptcy

Lack of integration with

suppliers

Lack of suppliers

visibility

Supplier opportunism

requirements

Inability to handle volume

demand changes

Inability to meet quality

requirements

Suppliers' dependency

Transport providers'

fragmentation

Damages in transport

2

Supply responsiveness

RISKS

\section{Global outsourcing}

Cannot provide

competitive pricing

Accidents in transportation

Transportation breakdowns

Port strikes

Port capacity and

congestion

Custom clearance at ports

Higher costs of

transportation

Inventory holding cost

Design changes

Technological change

Warehouse and production disruption

Operator absence

Labour disputes/ strikes

Employee accidents

issatisfaction with work

Lack of experience or

training

Working conditions

Product obsolescence

Production

capabilities/capacity

Products quality and safety

Shorter life time products

Insufficient maintenance

\begin{tabular}{ll} 
& $\begin{array}{l}\text { High competition in the } \\
\text { market } \\
\text { Inaccurate demand forecasts } \\
\text { Demand uncertainty } \\
\text { Market changes }\end{array}$ \\
\hline $\begin{array}{l}\text { Transport providers' } \\
\text { fragmentation } \\
\text { Damages in transport }\end{array}$ & $\begin{array}{l}\text { Customer dependency } \\
\text { Customer fragmentation }\end{array}$ \\
\hline $\begin{array}{l}\text { Accidents in transportation } \\
\text { High level of service required } \\
\text { by customers } \\
\text { Deficient or missing customer } \\
\text { relation management function }\end{array}$ \\
\hline $\begin{array}{l}\text { Port strikes } \\
\text { Port capacity and } \\
\text { congestion } \\
\begin{array}{l}\text { Custom clearance at ports } \\
\text { Higher costs of } \\
\text { transportation }\end{array}\end{array}$ & $\begin{array}{l}\text { Low in-house production } \\
\text { Order fulfilment errors }\end{array}$ \\
\hline
\end{tabular}

3*

*Risks at the row of 1 and 3 are likely to occur at all five sections in the supply chain. 
Table 2. Supply chain performance indicators

\begin{tabular}{|c|c|c|c|c|c|}
\hline & $\begin{array}{c}\text { Supplier } \\
\text { performance }\end{array}$ & Internal business & Innovation and learning & Customer service & Finance \\
\hline \multirow{5}{*}{$\begin{array}{l}\text { Supply chain } \\
\text { performance } \\
\text { indicators }\end{array}$} & Reliability & Amount of production waste & $\begin{array}{l}\text { Number of new product } \\
\text { developed per year }\end{array}$ & Delivery timeliness & Market share growth \\
\hline & \multirow[t]{4}{*}{ Response time } & Costs of inventory management & \multirow[t]{4}{*}{ Workforce flexibility } & $\begin{array}{l}\text { Percentage of "perfect orders" } \\
\text { delivered }\end{array}$ & \multirow[t]{4}{*}{ Return on Investments (ROI) } \\
\hline & & \multirow[t]{3}{*}{ Workforce productivity } & & $\begin{array}{l}\text { Product value perceived by the } \\
\text { customer }\end{array}$ & \\
\hline & & & & Product/ Service quality & \\
\hline & & & & $\begin{array}{l}\text { Response time to customer } \\
\text { queries }\end{array}$ & \\
\hline Authors & $\begin{array}{l}\text { (Gunasekaran et } \\
\text { 2010, Papakiriak }\end{array}$ & $\begin{array}{l}\text { 005, Chung et al., 2007, Bendo } \\
\text { los and Pramatari, 2010, Sarkis }\end{array}$ & $\begin{array}{l}\text { t al., 2007, Cuthbertson ar } \\
\text { al., 2010) }\end{array}$ & iotrowicz, 2008, Chae, 2009, W & t al., 2009, Taticchi et al., \\
\hline
\end{tabular}


Table 3. Survey sample description

Firm profile

\begin{tabular}{|c|c|c|c|c|c|}
\hline \multirow{5}{*}{$\begin{array}{l}\text { Operation } \\
\text { fields }\end{array}$} & $\begin{array}{l}\text { Building Material Manufacturing } \\
\text { (sand, stone, additive, etc.) }\end{array}$ & 15.8 & \multirow{6}{*}{$\begin{array}{l}\text { Years of } \\
\text { business }\end{array}$} & $<5$ years & 7.9 \\
\hline & Building Material Distribution & 23.3 & & $5-10$ years & 36.1 \\
\hline & Concrete production & 17.8 & & $10-20$ years & 43.6 \\
\hline & Construction executive & 35.7 & & $20-30$ years & 10.9 \\
\hline & $\begin{array}{l}\text { Design (architecture and } \\
\text { construction) }\end{array}$ & 7.4 & & $30-40$ years & 1 \\
\hline \multirow{4}{*}{$\begin{array}{l}\text { Full-time } \\
\text { employees }\end{array}$} & Less than 10 & 2.5 & & 40 - 50 years & 0.5 \\
\hline & $10-200$ & 35.2 & \multirow{3}{*}{$\begin{array}{l}\text { Authorized } \\
\text { capital }\end{array}$} & $\begin{array}{l}<20 \text { billion } \\
\text { VND }\end{array}$ & 5.4 \\
\hline & $200-300$ & 25.7 & & $\begin{array}{l}20-100 \\
\text { billion VND }\end{array}$ & 16.8 \\
\hline & More than 300 & 36.6 & & $\begin{array}{l}>100 \text { billion } \\
\text { VND }\end{array}$ & 77.8 \\
\hline
\end{tabular}

VND: Vietnamese Dong

\begin{tabular}{|c|c|c|c|c|c|}
\hline \multicolumn{3}{|c|}{ Firm profile } & \multicolumn{3}{|c|}{ Respondent profile } \\
\hline \multirow{6}{*}{$\begin{array}{l}\text { Years of } \\
\text { business }\end{array}$} & $<5$ years & 7.9 & \multirow{5}{*}{ Job title } & Top-level manager & 7.4 \\
\hline & $5-10$ years & 36.1 & & $\begin{array}{l}\text { Middle-level } \\
\text { manager }\end{array}$ & 23.3 \\
\hline & $10-20$ years & 43.6 & & First-level manager & 50.5 \\
\hline & 20 - 30 years & 10.9 & & Coordinator & 10.9 \\
\hline & $30-40$ years & 1 & & Others & 7.9 \\
\hline & $40-50$ years & 0.5 & \multirow{8}{*}{$\begin{array}{c}\text { Working } \\
\text { area }\end{array}$} & Purchasing & 5 \\
\hline \multirow{7}{*}{$\begin{array}{l}\text { Authorized } \\
\text { capital }\end{array}$} & $\begin{array}{l}<20 \text { billion } \\
\text { VND }\end{array}$ & 5.4 & & Logistics & 4.5 \\
\hline & $\begin{array}{l}20-100 \\
\text { billion VND }\end{array}$ & 16.8 & & Operations/ Projects & 59.3 \\
\hline & $\begin{array}{l}>100 \text { billion } \\
\text { VND }\end{array}$ & 77.8 & & Human Resources & 8.4 \\
\hline & & & & Risk Management & 5.4 \\
\hline & & & & Finance & 1.5 \\
\hline & & & & Sales & 12.9 \\
\hline & & & & Marketing & 3 \\
\hline
\end{tabular}


Table 4. EFA and Cronbach's Alpha results

\begin{tabular}{|c|c|c|c|c|c|c|c|c|c|c|c|c|}
\hline \multirow[b]{2}{*}{ Constructs } & \multirow[b]{2}{*}{ Observed items } & \multirow{2}{*}{ SR } & \multicolumn{2}{|c|}{ OR } & \multirow{2}{*}{ DR } & \multirow{2}{*}{ FR } & \multirow{2}{*}{ IR } & \multirow{2}{*}{ TR } & \multicolumn{2}{|c|}{ ER } & \multirow{2}{*}{$\begin{array}{c}\text { Item - } \\
\text { total } \\
\text { correlation }\end{array}$} & \multirow{2}{*}{$\begin{array}{c}\text { Threshold } \\
\text { values }\end{array}$} \\
\hline & & & OR1 & OR2 & & & & & ER1 & ER2 & & \\
\hline $\mathrm{SR}^{*}$ & $\begin{array}{l}\text { Supplier bankruptcy } \\
\text { Price fluctuations } \\
\text { Unstable quality of inputs } \\
\text { Unstable quantity of inputs }\end{array}$ & $\begin{array}{l}.865 \\
.788 \\
.667 \\
.737\end{array}$ & $\begin{array}{r}-.050 \\
-.079 \\
.193 \\
.030\end{array}$ & $\begin{array}{r}.030 \\
-.277 \\
.348 \\
.042\end{array}$ & $\begin{array}{r}.014 \\
-.046 \\
.077 \\
.221\end{array}$ & $\begin{array}{r}-.011 \\
-.011 \\
.008 \\
.106\end{array}$ & $\begin{array}{r}.179 \\
.002 \\
-.047 \\
.165\end{array}$ & $\begin{array}{l}.133 \\
.175 \\
.116 \\
.302\end{array}$ & $\begin{array}{r}-.013 \\
-.075 \\
.215 \\
.017\end{array}$ & $\begin{array}{l}.123 \\
.111 \\
.297 \\
.066\end{array}$ & $\begin{array}{l}.770 \\
.611 \\
.559 \\
.679\end{array}$ & \multirow{9}{*}{ 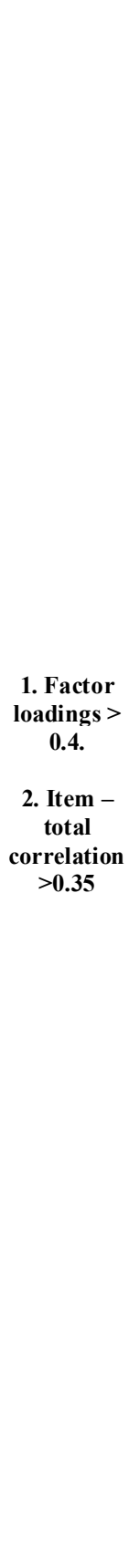 } \\
\hline $\mathrm{OR}^{*}$ & $\begin{array}{l}\text { Design changes } \\
\text { Technological changes } \\
\text { Accidents } \\
\text { Labour disputes }\end{array}$ & $\begin{array}{r}-.024 \\
.015 \\
.196 \\
.234\end{array}$ & $\begin{array}{r}.878 \\
.873 \\
-0 \frac{1}{.095} \\
.038\end{array}$ & $\begin{array}{l}.078 \\
-.030 \\
\frac{.839}{.825}\end{array}$ & $\begin{array}{r}-.055 \\
.055 \\
.039 \\
.107\end{array}$ & $\begin{array}{l}.088 \\
.059 \\
.051 \\
-.036\end{array}$ & $\begin{array}{l}.185 \\
.118 \\
-.015 \\
-.174\end{array}$ & $\begin{array}{l}-.025 \\
-.027 \\
.047 \\
-.035\end{array}$ & $\begin{array}{r}.124 \\
.248 \\
-.032 \\
.050\end{array}$ & $\begin{array}{l}-.121 \\
.006 \\
-.085 \\
-.062\end{array}$ & $\begin{array}{l}.778 \\
.778 \\
.696 \\
.696\end{array}$ & \\
\hline $\mathrm{DR}^{*}$ & $\begin{array}{l}\text { Demand variability } \\
\text { High competition in the market } \\
\text { Customer bankruptcy } \\
\text { Customer fragmentation }\end{array}$ & $\begin{array}{l}.147 \\
.024 \\
.034 \\
.016\end{array}$ & $\begin{array}{l}-.073 \\
.129 \\
-.001 \\
-.052\end{array}$ & $\begin{array}{r}-.378 \\
.013 \\
.081 \\
.129\end{array}$ & $\begin{array}{l}.763 \\
.717 \\
.819 \\
.842\end{array}$ & $\begin{array}{r}.086 \\
.036 \\
.078 \\
-.074\end{array}$ & $\begin{array}{l}.062 \\
.235 \\
-.191 \\
-.057\end{array}$ & $\begin{array}{l}.123 \\
.135 \\
.000 \\
.137\end{array}$ & $\begin{array}{l}-.027 \\
-.002 \\
.029 \\
.017\end{array}$ & $\begin{array}{r}.020 \\
-.117 \\
.173 \\
.022\end{array}$ & $\begin{array}{l}.625 \\
.551 \\
.658 \\
.696\end{array}$ & \\
\hline \multirow[t]{2}{*}{$\mathrm{FR}^{*}$} & $\begin{array}{l}\text { Currency fluctuations } \\
\text { Inflation } \\
\text { Interest rate level }\end{array}$ & $\begin{array}{l}-.013 \\
.021 \\
.056\end{array}$ & $\begin{array}{l}.134 \\
.045 \\
-.051\end{array}$ & $\begin{array}{r}-.056 \\
.386 \\
-.162\end{array}$ & $\begin{array}{l}.051 \\
.042 \\
.006\end{array}$ & $\begin{array}{l}.861 \\
.733 \\
.825\end{array}$ & $\begin{array}{r}-.026 \\
.074 \\
.072\end{array}$ & $\begin{array}{l}-.105 \\
-.001 \\
.209\end{array}$ & $\begin{array}{l}.089 \\
.214 \\
-.020\end{array}$ & $\begin{array}{l}.020 \\
.021 \\
.143\end{array}$ & $\begin{array}{l}.671 \\
.538 \\
.596\end{array}$ & \\
\hline & $\begin{array}{l}\text { Stakeholders (request late } \\
\text { changes, new stakeholders, etc.) }\end{array}$ & \multicolumn{10}{|c|}{ Deleted } & \\
\hline $\mathrm{IR}^{*}$ & $\begin{array}{l}\text { Communication breakdown with } \\
\text { project team } \\
\text { Information infrastructure } \\
\text { breakdown } \\
\text { Distorted information }\end{array}$ & $\begin{array}{l}.102 \\
.011 \\
.209\end{array}$ & $\begin{array}{l}.090 \\
.196 \\
.023\end{array}$ & $\begin{array}{r}.040 \\
.080 \\
-.170\end{array}$ & $\begin{array}{r}.066 \\
.000 \\
-.081\end{array}$ & $\begin{array}{l}.060 \\
.035 \\
-.001\end{array}$ & $\begin{array}{l}.876 \\
.885 \\
.805\end{array}$ & $\begin{array}{l}.188 \\
.112 \\
.329\end{array}$ & $\begin{array}{l}.045 \\
.173 \\
.047\end{array}$ & $\begin{array}{l}-.074 \\
-.024 \\
-.010\end{array}$ & $\begin{array}{l}.803 \\
.796 \\
.762\end{array}$ & \\
\hline $\mathrm{TR}^{*}$ & $\begin{array}{l}\text { Delays in supply activities } \\
\text { Delays in operating activities } \\
\text { Delays in distribution activities } \\
\text { Delayed payment } \\
\text { Information delays }\end{array}$ & $\begin{array}{l}.293 \\
.012 \\
.285 \\
.189 \\
.107\end{array}$ & $\begin{array}{l}-.220 \\
-.236 \\
-.084 \\
.111 \\
.211\end{array}$ & $\begin{array}{r}.043 \\
.186 \\
-.249 \\
.113 \\
-.115\end{array}$ & $\begin{array}{l}.239 \\
.098 \\
.091 \\
.137 \\
.015\end{array}$ & $\begin{array}{l}-.143 \\
-.048 \\
.022 \\
.145 \\
.096\end{array}$ & $\begin{array}{l}.076 \\
.218 \\
.160 \\
.291 \\
.064\end{array}$ & $\begin{array}{l}.683 \\
.726 \\
.740 \\
.686 \\
.823\end{array}$ & $\begin{array}{r}.016 \\
.022 \\
.111 \\
-.050 \\
.093\end{array}$ & $\begin{array}{l}.073 \\
.186 \\
.044 \\
.017 \\
.121\end{array}$ & $\begin{array}{l}.667 \\
.651 \\
.692 \\
.634 \\
.668\end{array}$ & \\
\hline \multirow[t]{2}{*}{$\mathrm{ER}^{*}$} & $\begin{array}{l}\text { Economic downturns } \\
\text { External legal issues } \\
\text { Corruption } \\
\text { Fire accidents } \\
\text { Natural catastrophes }\end{array}$ & $\begin{array}{r}.054 \\
.025 \\
-.035 \\
-.021 \\
.019\end{array}$ & $\begin{array}{l}.114 \\
.176 \\
.057 \\
-.298 \\
-.409\end{array}$ & $\begin{array}{r}.130 \\
-.246 \\
.099 \\
.189 \\
.108\end{array}$ & $\begin{array}{l}.081 \\
-.094 \\
.019 \\
-.006 \\
-.110\end{array}$ & $\begin{array}{r}.153 \\
.098 \\
-.011 \\
.111 \\
.230\end{array}$ & $\begin{array}{l}.162 \\
.051 \\
.019 \\
.114 \\
-.005\end{array}$ & $\begin{array}{r}-.007 \\
.101 \\
.051 \\
.323 \\
.337\end{array}$ & $\begin{array}{r}.762 \\
.760 \\
.828 \\
.039 \\
.110\end{array}$ & $\begin{array}{r}.012 \\
.085 \\
-.001 \\
-.712 \\
.633\end{array}$ & $\begin{array}{r}.568 \\
.541 \\
.551 \\
.762 \\
.762\end{array}$ & \\
\hline & Cultural differentiation & \multicolumn{10}{|c|}{ Deleted } & \\
\hline \multicolumn{2}{|c|}{ Cronbach's alpha } & .824 & .875 & .821 & .812 & .767 & .883 & .849 & .728 & .865 & & $>0.7$ \\
\hline \multicolumn{2}{|c|}{ Total variance extracted } & \multicolumn{9}{|c|}{76.034} & & $>\mathbf{5 0} \%$ \\
\hline
\end{tabular}

*SR: Supply risk; OR: Operational risk; DR: Demand risk; FR: Finance risk; IR: Information risk; TR: Time risk; ER: External risk. 
Table 5. CFA results

\begin{tabular}{|c|c|c|c|c|}
\hline & Constructs & $\begin{array}{c}\text { Standardized } \\
\text { Regression Weights } \\
\end{array}$ & $\begin{array}{c}\text { Standard } \\
\text { errors }\end{array}$ & $\mathbf{R}^{2}$ \\
\hline \multirow{4}{*}{ SR } & Supplier bankruptcy & 0.939 & 0.044 & 0.881 \\
\hline & Price fluctuations & 0.721 & 0.058 & 0.519 \\
\hline & Unstable quality of inputs & 0.565 & 0.060 & 0.319 \\
\hline & Unstable quantity of inputs & 0.689 & 0.060 & 0.475 \\
\hline \multirow{4}{*}{ OR } & Design changes & 0.863 & 0.058 & 0.746 \\
\hline & Technological changes & 0.901 & 0.054 & 0.812 \\
\hline & Accidents & 0.848 & 0.055 & 0.72 \\
\hline & Labour disputes & 0.82 & 0.059 & 0.672 \\
\hline \multirow{4}{*}{ DR } & Demand variability & 0.641 & 0.045 & 0.41 \\
\hline & High competition in the market & 0.549 & 0.034 & 0.301 \\
\hline & Customer bankruptcy & 0.786 & 0.035 & 0.618 \\
\hline & Customer fragmentation & 0.85 & 0.042 & 0.723 \\
\hline \multirow{4}{*}{ FR } & Currency fluctuations & 0.864 & 0.068 & 0.747 \\
\hline & Inflation & 0.645 & 0.056 & 0.417 \\
\hline & Interest rate level & 0.674 & 0.051 & 0.454 \\
\hline & $\begin{array}{l}\text { Stakeholders (request late changes, new } \\
\text { stakeholders, etc.) }\end{array}$ & \multicolumn{3}{|c|}{ Deleted } \\
\hline & Communication breakdown with project team & 0.879 & 0.033 & 0.773 \\
\hline IR & Information infrastructure breakdown & 0.883 & 0.047 & 0.78 \\
\hline & Distorted information & 0.807 & 0.064 & 0.651 \\
\hline \multirow{5}{*}{ TR } & Delays in supply activities & 0.784 & 0.051 & 0.615 \\
\hline & Delays in operating activities & 0.686 & 0.053 & 0.471 \\
\hline & Delays in distribution activities & 0.759 & 0.052 & 0.576 \\
\hline & Delayed payment & 0.685 & 0.044 & 0.469 \\
\hline & Information delays & 0.797 & 0.033 & 0.635 \\
\hline \multirow{6}{*}{ ER } & Economic downturns & 0.713 & 5.855 & 0.509 \\
\hline & External legal issues & 0.672 & 6.735 & 0.451 \\
\hline & Corruption & 0.686 & 6.446 & 0.47 \\
\hline & Fire accidents & 0.862 & 5.008 & 0.743 \\
\hline & Natural catastrophes & 0.884 & 4.241 & 0.782 \\
\hline & Cultural differentiation & \multicolumn{3}{|c|}{ Deleted } \\
\hline & Threshold values & \multicolumn{3}{|c|}{$\begin{array}{l}\text { 1. Standardized Regression Coefficients }>0.5 \text {. } \\
\text { 2. Standardized Regression Coefficient }>2 x \text { standard error. } \\
\text { 3. } R^{2}>0.3 \text {. }\end{array}$} \\
\hline
\end{tabular}


Table 6. Goodness of fit of measurement models

\begin{tabular}{|c|c|c|c|c|c|c|c|c|}
\hline & SR & OR & DR & FR & IR & TR & ER & Threshold values \\
\hline $\mathrm{p}$ & 0.258 & 0.304 & .602 & 0.303 & 0.560 & 0.142 & 0.360 & $>0.05$ \\
\hline$\chi^{2 / \mathrm{df}}$ & 1.280 & 1.190 & .272 & 1.061 & 0.340 & 1.721 & 1.097 & $<3.0$ \\
\hline CFI & 0.999 & 0.999 & 1.000 & 1.000 & 1.000 & 0.993 & 0.998 & $>0.9$ \\
\hline RMSEA & 0.037 & 0.031 & 0.000 & 0.017 & 0.000 & 0.060 & 0.022 & $<0.08$ \\
\hline
\end{tabular}

Table 7. Chi-square difference among research concepts

\begin{tabular}{lrrrrrr}
\hline & \multicolumn{1}{c}{ SR } & OR & DR & FR & IR & \\
\hline SR & 1 & & & & \\
OR & 107.322 & 1 & & & \\
DR & 108.325 & 148.18 & 1 & & \\
FR & 136.53 & 144.258 & 147.925 & 1 & \\
IR & 62.497 & 93.906 & 106.697 & 99.725 & \\
TR & 75.923 & 150.847 & 113.673 & 151.483 & 1 \\
ER & 130.613 & 140.369 & 161.29 & 136.295 & 1 & \\
\end{tabular}

*All chi-square differences were significant at the 0.001 level 
Table 8. Pearson's correlation coefficient

\begin{tabular}{|c|c|c|c|c|c|c|}
\hline \multicolumn{7}{|c|}{ CORE RISKS \& SUPPLY CHAIN PERFORMANCE } \\
\hline & & \multicolumn{5}{|c|}{ SUPPLY CHAIN PERFORMANCE } \\
\hline & & Supplier performance & Internal business & Innovation and learning & Customer service & Financial indicators \\
\hline SR & & $.237^{* *}$ & $.432^{* *}$ & -.004 & $.189^{* *}$ & .100 \\
\hline OR & $\overline{\mathrm{OR}}$ & $-\frac{-.057}{-.070}--$ & $-\frac{.287 * *}{.147^{*}}-$ & $\frac{.197 * *}{.143^{*}}-$ & $\frac{.153^{*}}{.156^{*}}=$ & $-\frac{.102}{.034}-$ \\
\hline DR & I & $\frac{-.011}{.120}$ & $\frac{.259^{* *}}{.124}$ & .135 & $-\frac{.061}{.065}-$ & $--\frac{.110}{.004}$ \\
\hline
\end{tabular}

\begin{tabular}{|c|c|c|c|c|c|c|c|c|c|c|}
\hline & SR & $\begin{array}{l}\text { RAST } \\
\text { OR }\end{array}$ & I & $\begin{array}{l}\text { CTUR } \\
\text { OR1 }\end{array}$ & $\begin{array}{c}\text { RISKS } \\
\text { OR2 }\end{array}$ & $\begin{array}{l}\mathcal{8} \\
\mathbf{1}\end{array}$ & $\begin{array}{c}\text { CORE } \\
\text { DR }\end{array}$ & $\begin{array}{l}\text { KS } \\
\text { FR }\end{array}$ & IR & TR \\
\hline FR & .083 & $.180^{*}$ & I & $.151^{*}$ & .104 & I & .079 & & & \\
\hline IR & $.253^{* *}$ & .127 & I & $.267^{* *}$ & -.087 & I & .038 & .108 & & \\
\hline TR & $.461^{* *}$ & .092 & I & -.048 & $.178^{*}$ & 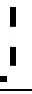 & $.271^{* *}$ & .092 & $.426^{* *}$ & \\
\hline
\end{tabular}

EXTERNAL RISKS ON INFRASTRUCTURE RISKS \& CORE RISKS

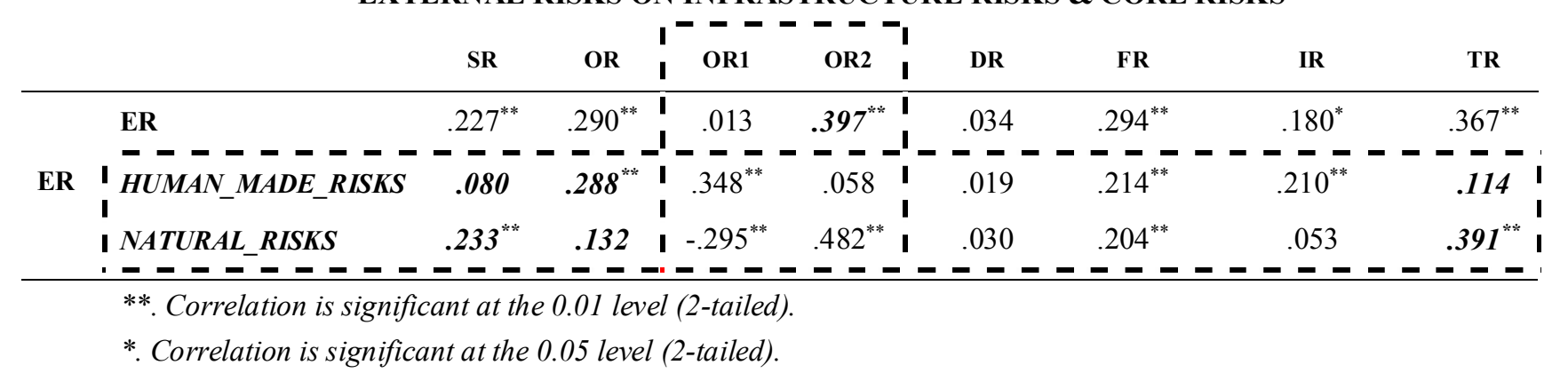


MONITORING I

MITIGATION

ASSESSMENT

IDENTFICATION

\begin{tabular}{|c|c|c|c|c|}
\hline & IDENTFICATION & ASSESSMENT & MITIGATION & MONITORING \\
\hline — Qualitative studies & 5 & 6 & 17 & $\mathbf{0}$ \\
\hline - Analytical studies & 1 & 54 & 78 & 1 \\
\hline Empirical studies & 1 & 2 & 6 & $\mathbf{0}$ \\
\hline
\end{tabular}

*There are two journal articles conducting an integrated process that two processes took into account concurrently.

Figure 1. Distribution of research methods over the last 14 years

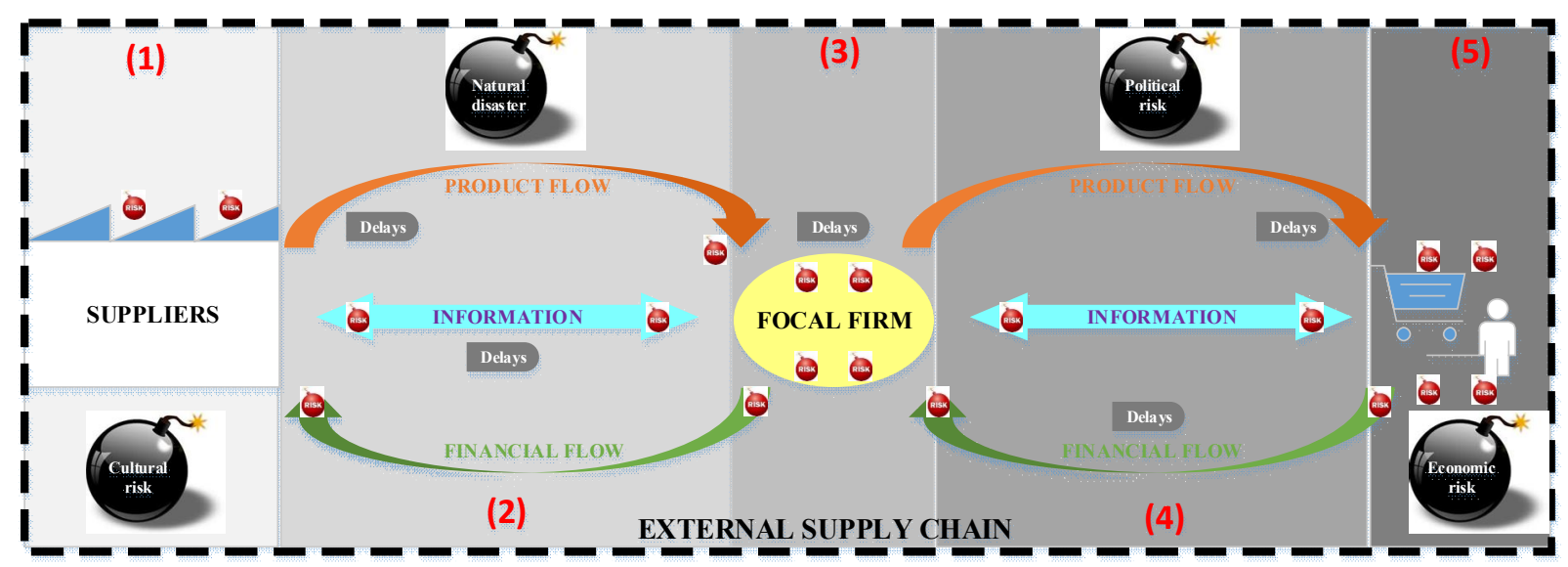

Figure 2. Supply chain map

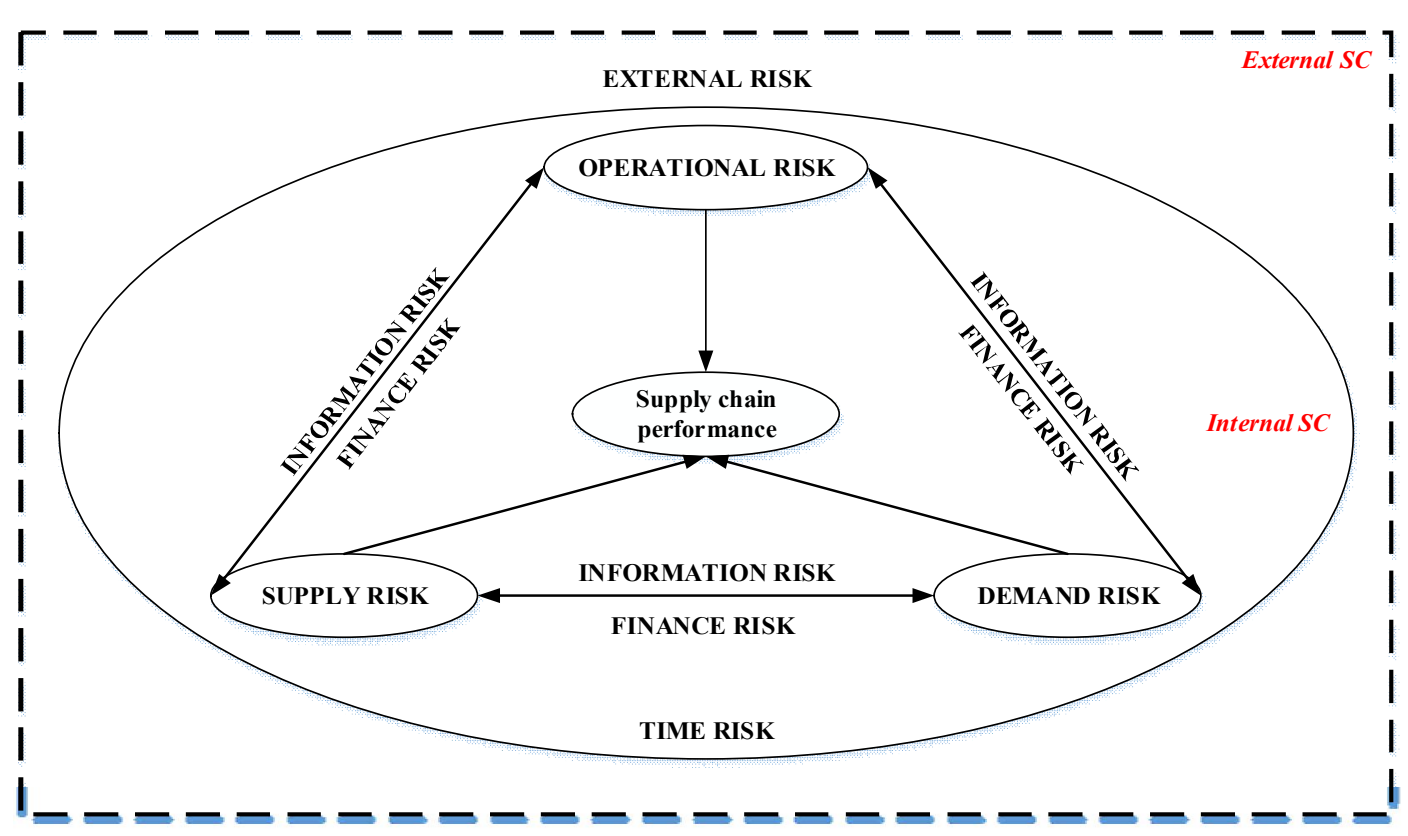

Figure 3. Theoretical conceptual framework 

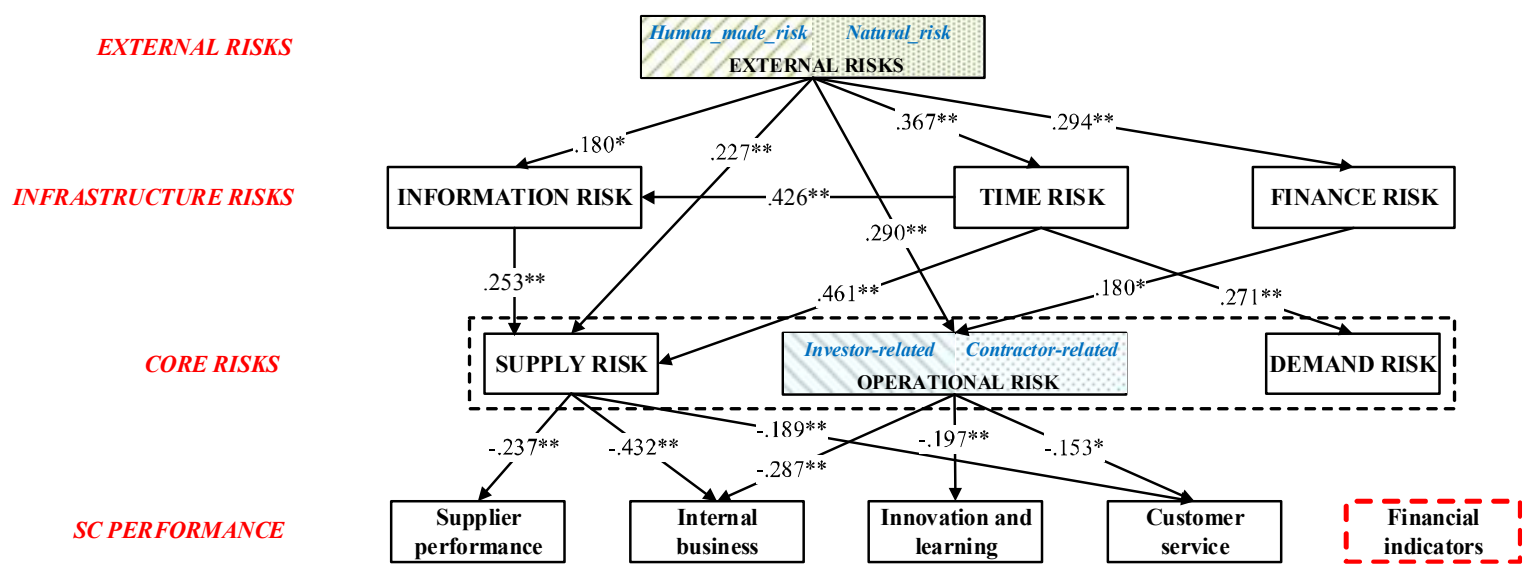

Figure 4. Result model 